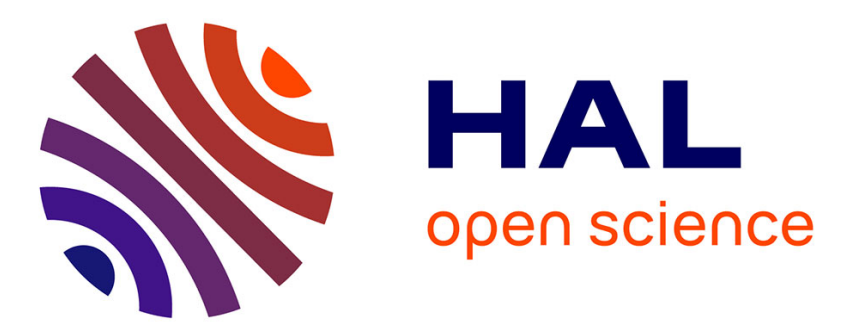

\title{
X-linked hypophosphatemia: Management and treatment prospects
}

\author{
Anne-Sophie Lambert, Volha Zhukouskaya, Anya Rothenbuhler, Agnès \\ Linglart
}

\section{- To cite this version:}

Anne-Sophie Lambert, Volha Zhukouskaya, Anya Rothenbuhler, Agnès Linglart. X-linked hypophosphatemia: Management and treatment prospects. Joint Bone Spine, 2019, 86, pp.731 - 738. 10.1016/j.jbspin.2019.01.012 . hal-03489008

\section{HAL Id: hal-03489008 https://hal.science/hal-03489008}

Submitted on 21 Dec 2021

HAL is a multi-disciplinary open access archive for the deposit and dissemination of scientific research documents, whether they are published or not. The documents may come from teaching and research institutions in France or abroad, or from public or private research centers.
L'archive ouverte pluridisciplinaire HAL, est destinée au dépôt et à la diffusion de documents scientifiques de niveau recherche, publiés ou non, émanant des établissements d'enseignement et de recherche français ou étrangers, des laboratoires publics ou privés.

\section{다)(1) $(5$}

Distributed under a Creative Commons Attribution - NonCommerciall 4.0 International 


\title{
X-Linked Hypophosphatemia: Management and Treatment Prospects
}

\author{
Anne-Sophie Lambert ${ }^{1,2}$, Volha Zhukouskaya ${ }^{3}$, Anya Rothenbuhler ${ }^{1,2}$, Agnès
}

\section{Linglart ${ }^{1,2,4}$}

1. Centre de référence des maladies rares du métabolisme du calcium et du phosphate, filière OSCAR and Plateforme d'Expertise Maladies Rares Paris-Sud, Hôpital Bicêtre Paris Sud, APHP, 94270 Le Kremlin Bicêtre, France

2. Endocrinologie et diabète de l'enfant, Hôpital Bicêtre Paris Sud, APHP, 94270 Le Kremlin Bicêtre, France

3. Division of Endocrinology, Department of Clinical Medicine and Surgery, University "Federico II" of Naples, Naples, Italy

4. INSERM U1185 et université Paris Sud Paris-Saclay, Hôpital Bicêtre Paris Sud, 94270 Le Kremlin Bicêtre, France

\section{Corresponding author: Agnès Linglart}

Hôpital Bicêtre, Endocrinologie and diabete de l'enfant, 64 boulevard Gabriel Péri, 94270

Le Kremlin Bicêtre, FRANCE

Tel.: +33 145217 853; Fax: +33145217850

E-mail: agnes.linglart@aphp.fr 


\section{ABSTRACT}

X-linked hypophosphatemia (XLH), due to a PHEX gene mutation, is the most common genetic form of rickets and osteomalacia. Manifestations in children consist of rickets, lower-limb bone deformities, bone pain, failure to thrive, dental abscesses, and/or craniostenosis. Adults may present with persistent bone pain, early osteoarthritis, hairline fractures and Looser zones, enthesopathy, and/or periodontitis. Regardless of whether the patient is an infant, child, adolescent or adult, an early diagnosis followed by optimal treatment is crucial to control the clinical manifestations, prevent complications, and improve quality of life. Treatment options include active vitamin D analogs and phosphate supplementation to correct the $1,25(\mathrm{OH})_{2}$ vitamin D deficiency and to compensate for the renal phosphate wasting, respectively. The recently introduced FGF23 antagonist burosumab is designed to restore renal phosphate reabsorption by the proximal tubule and to stimulate endogenous calcitriol production. In Europe, burosumab is licensed for use in pediatric patients older than 1 year who have XLH. This review discusses the diagnosis and treatment of XLH and describes the indications of the various available treatments.

Keywords: X-linked hypophosphatemia., PHEX. Rickets. Vitamin D analogs. Dental abscess. FGF23. Burosumab. 


\section{Introduction}

X-linked hypophosphatemia (XLH), caused by a loss-of-function mutation in the PHEX gene (1), and is the most common form of genetically determined hypophosphatemia. The main manifestation in infants is rickets, which develops when the patient starts to walk. Children and adolescents usually present with lower limb deformities that persist despite vitamin D supplementation. Presenting symptoms in adults may consist of persistent bone pain, early osteoarthritis, hairline fractures, and Looser zones. These manifestations are particularly suggestive when combined with tooth loss and/or periodontitis. Regardless of whether the patient is an infant, child, adolescent, or adult, an early diagnosis followed by optimal treatment is crucial to control the clinical manifestations, prevent complications, and improve quality of life (2-4). To data, no information on the natural history of XLH is available from registries or large clinical studies. This lack of data hinders the distinction between complications of XLH, such as enthesopathy and hyperparathyroidism, and adverse effects of long-term phosphate supplementation and vitamin D analog therapy, such as nephrocalcinosis. Given the disabilities induced by XLH and quality-of-life impairments identified in the fifth decade of life (4), treatments initiated in childhood and adolescents can be expected to provide long-term benefits.

\section{Diagnosis of X-linked hypophosphatemia (XLH)}

Studies in children indicate that an early diagnosis allowing early treatment initiation improves the long-term outcomes. Growth velocity and final height increase and improvements occur in bone shape and mineralization, as well as in dental mineralization $(5-8)$.

\subsection{Diagnosis in pediatric patients with affected relatives}


About $85 \%-90 \%$ of patients with familial hypophosphatemic rickets harbor PHEX mutations $(1,9)$. XLH is an X-linked disease with dominant inheritance. Affected males transmit the condition to all their daughters and none of their sons. Affected females have a $50 \%$ risk of transmitting the disease to each of their children. Parents should be informed, if possible prior to conception, about the risk of transmitting the disease and about the management strategy for affected neonates. XLH can be diagnosed by examining a cord blood sample for the PHEX mutation known to exist in the family and/or starting by testing the neonate for hypophosphatemia at 7 days of age. The neonate should undergo serum phosphate, creatinine, and alkaline phosphatase assays and measurements of urine phosphate and creatinine excretion to allow determination of the tubular reabsorption of phosphate rate (TRP), which can be corrected for the glomerular filtration rate (TmP/GFR) (10). A serum phosphate level near or below the lower limit of normal for age combined with increased renal phosphate excretion suggests XLH. In a study of 52 pediatric patients, mean serum phosphate was $0.91 \pm 0.2 \mathrm{mmol} / \mathrm{L}$ (range, $0.55-1.50 \mathrm{mmol} / \mathrm{L}$ ). As neonates may not yet have developed evidence of rickets and may still have serum phosphate levels within the normal range, the assays should be repeated after a few months in the absence of confirmation by genetic testing. The serum phosphate and alkaline phosphatase levels should be interpreted according to age. In neonates, normal serum phosphate levels are about twice those found in adults (11).

The very early diagnosis of XLH followed immediately by appropriate treatment prevents the development of clinical rickets, thus avoiding lower-limb deformities. In the long-term, another potential benefit is prevention of rheumatic complications. The diagnosis may be delayed, however, although one of the parents is necessarily affected. Adults with XLH may have discontinued their follow-up, for instance because they did not receive adequate information or did not perceive the risk of transmission to their offspring. In our 
cohort of 58 patients with familial XLH, median age at diagnosis was 1.3 years but ranged from birth to 14.3 years.

\subsection{Diagnosis of de novo $\mathrm{XLH}$ in pediatric patients}

The most prominent clinical manifestations are due to inadequate mineralization of the bones and teeth. PHEX mutations are identified in about one-third of pediatric patients with newly diagnosed hypophosphatemic rickets. Diagnostic wanderings translate into delays of 9 months to 13.1 years (mean, $3.9 \pm 3.1$ years).

\subsection{Presenting manifestations of XLH in pediatric patients}

Rickets is the cardinal manifestation of XLH. At the lower limbs, varus deformity develops in younger children and valgus deformity in children nearing pubertal age. The varus deformity develops as soon as the patient learns to stand and walk. Other symptoms include a waddling gait and pain in the bones and joints, particularly after prolonged walking and at night. Due to the lower-limb deformities, the patient is often seen first by an orthopedic surgeon. Because some degree of varus is normal in infants (12), the deformity is often disregarded in patients younger than 2 years, resulting in diagnostic delays. Although growth velocity is consistently decreased, slow statural growth is the reason for the diagnosis in only $14 \%$ of patients.

In addition to the lower-limb deformities and slow growth velocity, the manifestations may include joint enlargement without evidence of inflammation, dolichocephaly, craniostenosis, dental abscesses and, in some patients, severe infections such as facial cellulitis spreading from a dental focus (6). The dental abscesses are due to insufficient dentin mineralization with the development of cracks through which systemic bacteria can penetrate. The typical radiographic signs of rickets consist of lower-limb deformities 
combined with generalized growth-plate abnormalities that predominate at the fastestgrowing metaphyses such as the distal femur, proximal tibia, and wrist, which are enlarged and have ill-defined contours. In contrast to rickets caused by impairments in vitamin D metabolism, there is no evidence of bone resorption, and the cortices tend instead to be thick and compact (Figure 1) $(3,8)$.

A number of biochemical findings support the diagnosis of XLH. Serum alkaline phosphatase levels are high, indicating a diagnosis of rickets. However, at the time of diagnosis, they are significantly lower in XLH than in rickets due to vitamin D metabolism impairments. Thus, in 21 patients with de novo XLH seen at a referral center, the mean serum alkaline level at diagnosis was 636 $\pm 291 \mathrm{IU} / \mathrm{L}$ (normal, <400 IU/L), compared to $1831 \pm 1297$ IU/L in 37 pediatric patients with vitamin D receptor gene mutations (unpublished data). The serum phosphate level is below the normal range for age. The TRP and/or TmP/GFR values indicate renal phosphate wasting (10). In a patient with hypophosphatemia, even TRP and/or TmP/GFR values toward the lower end of the normal range should be viewed as abnormal. The serum parathyroid level is near the upper limit of normal. In our referral center cohort, the mean value at diagnosis was $42 \pm 18 \mathrm{pg} / \mathrm{mL}$ (range, 8-86 pg/mL; normal, $15-50 \mathrm{pg} / \mathrm{mL})$. Serum calcium levels are normal or at the lower end of the normal range, and urinary calcium excretion is low. Finally, there is no evidence of proximal or distal tubulopathy.

\subsection{Diagnosis in adults}

The diagnosis may be established during investigations in the relatives of an index patient. In the absence of symptoms, no imaging studies should be performed, and treatment is unnecessary. Far more often, however, the abnormality that triggers the diagnostic workup is chronic bone or joint pain or hypophosphatemia. The medical interview may reveal a 
childhood history of rickets; surgical procedures, often on multiple occasions, to treat lowerlimb deformities; repeated treatments for dental problems; and delayed growth. The patient may report having received follow-up and/or multiple treatments for bone and joint pain, early osteoarthritis, or polyarthritis without convincing evidence of inflammation. The physical examination may disclose varus or valgus deformities of the lower limbs, small stature, an unusual gait, and/or a variable degree of disability ranging from minimal to being confined to a wheelchair (Figure 2) $(2,3,13,14)$.

Musculoskeletal presenting symptoms usually lead to a radiographic evaluation. The radiographs should be centered on the painful sites. In compliance with EURATOM 2013/59 directives aimed at limiting radiation exposure related to investigations (15), preference should be given to $\mathrm{EOS}^{\circledR}$ imaging in the standing position, which diminishes patient radiation exposure by $70 \%$ to $80 \%$ compared to standard radiography. Radiographs are useful for quantifying the skeletal deformities, assessing joint alignment, diagnosing fractures and Looser zones (pseudo-fractures), and evaluating enthesopathies. Enthesopathies may develop starting at 40 years of age (16-19).

As with pediatric patients, the main biochemical abnormalities in adults with XLH are hypophosphatemia and renal phosphate wasting. A tendency toward hyperparathyroidism may result in elevated PTH, serum calcium, and urinary calcium levels, even at diagnosis $(20,21)$. Bone phosphatase alkaline levels are generally elevated, contributing to the diagnosis.

In sum, thorough familiarity with the clinical and biochemical signs of renal phosphate wasting ensures the diagnosis of XLH (Table 1). Confirmation can be obtained by a circulating intact FGF23 assay. However, the values are significantly lower in patients with XLH compared to those with oncogenic osteomalacia (22). Furthermore, several factors influence the FGF23 level, including chronic phosphate supplementation (23). 
The definitive diagnosis of XLH is provided by genetic testing, which identifies a lossof-function mutation in the PHEX gene. Several experimental genetic approaches may be required, however, as the causal mutations cover a broad spectrum encompassing insertions/deletions, point mutations, extensive deletions, pseudoexon deletions, and mosaicism $(2,3)$.

\section{Disease severity and complications}

$\mathrm{XLH}$ is a multisystem disease that evolves throughout life. The manifestations may include dental abscesses, taurodontism, facial cellulitis and periodontitis $(6,7)$; partial or complete premature closure of the cranial sutures, craniostenosis, dolichocephaly, Chiari malformation, syringomyelia, intracranial hypertension, and neurological signs (24); and hearing impairments (25). Statural growth may be slow, resulting in a short final height in about $50 \%$ of patients (26). Other manifestations include muscle function impairment (27); hyperparathyroidism (20); and overweight or obesity. Finally, patients may develop early osteoarthritis of the hips, knees, or ankles; fractures and Looser zones; and enthesopathies $(3,19)$.

Patients diagnosed with XLH should undergo comprehensive investigations to assess disease severity and detect any complications. Lower-limb alignment should be evaluated by measuring the intercondylar and intermalleolar distances, as well as the tibiofemoral angles. In patients older than 5 years, the 6-minute walking distance can be used as a measure of muscle function (28). Tests used to evaluate rickets or osteomalacia include serum assays of alkaline phosphatase, PTH, calcium, and phosphate; urinary calcium and phosphate excretion; and radiographs centered on open metaphyses in children and on painful sites in adults. The neurological examination should include fundoscopy and head circumference measurement. Patients who have suspected craniostenosis or neurological and/or 
ophthalmological evidence of intracranial hypertension should undergo brain imaging by computed tomography or magnetic resonance imaging. The teeth and periodontal tissues should be examined clinically and an orthopantomogram obtained in patients older than 5 years. In pediatric patients, growth velocity should be monitored and the final height predicted. Hearing tests are required in patients with hearing impairments. Renal function should be monitored by serial calcium excretion measurement and ultrasound scans and parathyroid function by repeated PTH assays. Blood pressure should be monitored and the body mass index computed to assess the cardiovascular risk. Finally, evaluation of the extent of the skeletal abnormalities may require $\operatorname{EOS}^{\circledR}$ imaging of the lower limbs and spine. Bone mineral density measurement may be in order in postmenopausal women.

\section{Differential diagnosis}

The diagnosis of XLH may be delayed by several years due to the similarities in the clinical, biochemical, and/or radiological abnormalities with those seen in other conditions. In pediatric patients, the gait abnormalities and deformities of the lower limbs and metaphyses may suggest metaphyseal dysplasia if the serum alkaline phosphatase is normal and hypophosphatasia if it is low. Adults may be mistakenly diagnosed with disorders responsible for early severe stiffness and/or with enthesopathies, such as ankylosing spondylitis and diffuse idiopathic skeletal hyperostosis. Finally, the most important differential diagnoses are the diseases that cause renal phosphate wasting with hypophosphatemia in the absence of PHEX gene mutations., i.e., chronic FGF23 elevation and primary renal tubule diseases. Chronic FGF23 elevation with phosphate wasting is seen in autosomal dominant rickets due to FGF23 mutations and types 1 and 2 autosomal recessive rickets due to $D M P 1$ and $E N P P 1$ mutations; rickets with hyperparathyroidism due to KLOTHO mutations; osteoglophonic dysplasia due to FGFRl mutations; and autonomous 
FGF23 secretion by tumor cells in oncogenic osteomalacia or by mosaics in patients with activating GNAS or $R A S$ mutations responsible for fibrous dysplasia and hypophosphatemic mucocutaneous syndrome. Primary renal tubule disorders can result in phosphate wasting. Examples include rickets with hypercalciuria due to $S L C 34 A 3$ mutations, X-linked recessive hypophosphatemic rickets due to CLCN5 mutations, hypophosphatemia with nephrocalcinosis, Fanconi syndrome, and proximal renal tubule disorders related to toxic agents or medications.

\section{Management}

Once the diagnosis of XLH is confirmed, the treatments goals are to minimize the functional impairments, restore lower-limb alignment, improve the mineralization of bones and teeth, and increase muscle strength. Attention should be given to therapeutic patient education and to social and familial factors. Follow-up should be provided to prevent the development of endocrine, rheumatic, and renal complications. In 2018, the French High Health Authority (HAS) and referral center for rare disorders of calcium and phosphate metabolism issued a nationwide protocol for the diagnosis and management of XLH (29).

Patients with XLH should be managed by a multidisciplinary team including a referral center expert in bone metabolism disorders, a radiologist, an orthopedic surgeon, a rheumatologist, an endocrinologist, a physical therapist, an otorhinolaryngologist, a neurosurgeon, a dentist, an orthodontist, a periodontist, a psychologist, and a social worker .

\subsection{Principles of management in pediatric patients}

There are currently two treatment options for pediatric XLH, whose availability varies from one country to the next. The conventional treatment combines an active vitamin D 
analog (calcitriol [Rocaltrol $\left.{ }^{\circledR}\right]$ or alfacalcidol [Unalpha $\left.{ }^{\circledR}\right]$ ) and phosphate supplementation. The other option is the monoclonal anti-FGF23 antibody burosumab. Because these two treatments act via different mechanisms, the treatment goals and follow-up modalities differ between them (Table 2).

\subsubsection{Conventional treatment}

The conventional strategy was first introduced in 1975 and was the only available treatment until 2018. It acts by compensating for the renal phosphate wasting and $1,25(\mathrm{OH})_{2}$ vitamin D deficiency caused by the high FGF23 levels. The recommended alfacalcidol [Unalpha ${ }^{\circledR}$ ] dosage is $1-2 \mathrm{ug} /$ day from birth to 10 years of age and 1.5 to $3 \mathrm{ug} /$ day between 10 and 15 years of age, in a single daily dose, preferably in the evening. Phosphate supplements are given in dosages of $40-60 \mathrm{mg} / \mathrm{kg} / \mathrm{day}$ from birth to 10 years of age, in four daily doses, for at least 1 year or until the patient starts school; and 30-50 mg/kg/day between 10 and 15 years of age. Vitamin D supplements are given also.

This conventional strategy lowers the alkaline phosphatase level to the upper limit of normal within about 1 year, partially or completely corrects the bone deformities (30) (Figure 3), increases growth velocity, increases height by about 1 standard deviation (5) and, finally, improves dental mineralization, thereby significantly decreasing the number of dental abscesses (6).

Limitations of this conventional strategy that have been pointed out over the years include persistence of the renal phosphate wasting and hypophosphatemia. The $1,25(\mathrm{OH})_{2}$ vitamin D deficiency also persists and carries a risk of secondary hyperparathyroidism, which is exacerbated by the chronic phosphate supplementation, potentially inducing rheumatic complications in adulthood. In addition, the hypercalciuria induced by active vitamin D analogs can induce nephrocalcinosis and renal dysfunction. Finally, no long-term clinical trial data are available for assessing the impact of the standard treatment strategy on 
the incidence of complications such as Chiari syndrome, craniostenosis, enthesopathies, hearing impairments, and/or fatigue.

\subsubsection{Burosumab}

Burosumab is a humanized monoclonal antibody directed against FGF23. It was recently licensed for children older than 1 year of age in Europe and for both children and adults in the US $(31,32)$. Burosumab counteracts the effects of FGF23, thereby restoring normal phosphate transporter expression, phosphate reabsorption by the proximal tubule, and endogenous $1,25(\mathrm{OH})_{2}$ vitamin D production, as well as improving the serum phosphate level.

In children aged 5 to 12 years, burosumab administered subcutaneously at 2-week intervals maintains the serum phosphate level at the lower end of the normal range (without inducing hyperphosphatemia), increases the $1,25(\mathrm{OH})_{2}$ vitamin $\mathrm{D}$ level, improves rickets scores within 40 weeks, and provides significant functional improvements with an increase in the 6-minute walking distance $(33,34)$.

The dosages should be adjusted to maintain satisfactory serum phosphate levels. In Europe, the recommended dosage is $0.4 \mathrm{mg} / \mathrm{kg} / 2$ weeks initially, followed if needed by dosage titration in $0.4 \mathrm{mg} / \mathrm{kg}$ increments up to $2 \mathrm{mg} / \mathrm{kg}$ or $90 \mathrm{mg}$.

Given the recent introduction of burosumab, no long-term data are available, notably regarding the incidence of hyperparathyroidism; renal function; and neurosurgical, ENT, and rheumatic complications. The limitations of burosumab therapy may include injection site reactions, only modest gains in bone growth, and the unfeasibility of adjusting the dosage to the calcium urinary excretion levels. 
At present, the conventional strategy is the first-line treatment in children with a known family history of XLH or an early diagnosis of de novo XLH. Burosumab should be used only at XLH referral centers. Burosumab therapy is considered in patients who fail to respond to optimal conventional treatment given for at least 1 year, to children with XLH diagnosed after 7-8 years of age, and to children who develop hyperparathyroidism or nephrocalcinosis during conventional therapy. The cost of burosumab treatment, which is several tens of thousands of Euros per year, should be weighed against the cost of managing the complications of XLH.

\subsubsection{Adjuvant treatments}

Growth hormone therapy (35) may deserve consideration in children with short stature despite optimal treatment for at least 1 year and near-normal alkaline phosphatase levels indicating control of the rickets. When given in combination with conventional XLH treatment, growth hormone seems to provide larger growth-rate increases when given before rather than after puberty (36).

The role for surgery to realign the lower limbs during growth should be determined during multidisciplinary discussions. In patients with idiopathic valgus of the knees (not due to XLH), techniques such as hemiepiphysiodesis are effective (37). In patients with XLH, no data are available to determine whether these procedures produce better skeletal alignment -without complications - than pharmacological therapy alone. Corrective surgery at the end of growth remains the safest option and is associated with the lowest risk of recurrence (30).

\subsection{Principles of management in adults}

Conventional treatment consisting in an active vitamin D analog with or without phosphate supplementation is effective on dental and periodontal complications (7), bone 
pain due to osteomalacia, fractures and Looser zones, and bone healing after fractures or surgical procedures (38). However, neither osteoarthritis nor enthesopathy is affected by this treatment approach (19). As patients go through adolescence then reach adulthood, they may experience complications such as hyperparathyroidism, periodontitis, hearing impairments, and enthesopathies. As a result, it may be difficult to decide whether to continue or stop the treatment after the end of growth or at the menopause. The current consensus among experts is that treatment should be provided to patients with bone pain, fractures, or Looser zones and to those who require orthopedic surgery. Despite the absence of evidence on this point, treatment is probably also warranted in postmenopausal women. In adults, administration of an active vitamin $\mathrm{D}$ analog is the mainstay of treatment. In general, the dosage is lower than in pediatric patients (calcitriol [Rocaltrol ${ }^{\circledR}$ ], 0.25-0.75 $\mu \mathrm{g} / \mathrm{day}$; alfacalcidol [Unalpha ${ }^{\circledR}$ ] 0.5$1.5 \mu \mathrm{g} /$ day). Phosphate supplements can be given also, in a dosage of up to $2500 \mathrm{mg} / \mathrm{day}$, but are not required and should not be used in patients with PTH elevation or true tertiary hyperparathyroidism $(20,21,39)$. Monitoring of treated patients should include urinary calcium excretion measurements, renal function tests, PTH assays, and renal imaging studies. Serum 25(OH) vitamin D levels should be kept within the normal range of 30-80 $\mathrm{ng} / \mathrm{mL}$.

In addition to the specific treatment of phosphate wasting, adults require body mass index monitoring and overall rheumatologic management tailored to each patient's capabilities and preferably involving a physical medicine and rehabilitation physician. Osteoarthritis should be treated in compliance with international guidelines for the management of osteoarthritis and the use of analgesics (40).

A randomized controlled trial has evaluated burosumab in 134 adults with XLH (41). In addition to correcting the biochemical abnormalities, burosumab induced improvements in stiffness, pain, and bone healing. Restless leg syndrome was observed in several patients 
in both the burosumab and placebo groups. As with children, real-life and long-term data are needed in adults, notably regarding the rheumatic complications.

\subsection{Therapeutic patient education (TPE)}

As soon as the diagnosis of XLH is established, the patient and family must be carefully informed to ensure treatment adherence. In addition, information on advances in research and treatments in the field of phosphate regulation should be given regularly. Contact information for patient self-help groups should be provided. Integration of the patient at school or work and within the wider social network should be optimized.

\section{Prospects}

XLH affects many organs and becomes symptomatic as soon as the patient starts to stand and walk. When treated suboptimally or not at all, XLH consistently induces complications such as bone pain, lower-limb deformities, oral complications including tooth loss, and/or very short stature. The disability varies in severity but is consistently obvious, adversely affecting function and psychological well-being. Patients are generally dissatisfied with their body image due to the appearance of their lower limbs and mouth. Difficulties with pronunciation cause further distress. The conventional treatment combining phosphate supplementation with an active vitamin D analog partially or completely restores normal bone shape, growth, and dental mineralization. However, it fails to correct the serum phosphate level. In addition, the response to conventional treatment is unsatisfactory in many patients. Considerable hope is therefore being placed in the recent licensing of the FGF23 antagonist burosumab for the treatment of XLH in children in Europe. Burosumab restores the serum phosphate level and endogenous production of active vitamin D to near- 
normal levels. However, neither long-term data nor data obtained under real-life conditions, as opposed to during clinical trials, are available to date for burosumab.

\section{Disclosure of interest}

ASL and VZ have no conflicts of interest to declare.

$\mathrm{AR}$ and $\mathrm{AL}$ are investigators in a clinical trial sponsored by Ultragenyx and have received honoraria from Kyowa Kirin for symposia in 2017 and 2018.

\section{Funding}

None 


\section{References}

1. A gene (PEX) with homologies to endopeptidases is mutated in patients with $\mathrm{X}$ linked hypophosphatemic rickets. The HYP Consortium. Nat Genet. 1995;11:130-6.

2. Carpenter TO, Imel EA, Holm IA, Jan de Beur SM, Insogna KL. A clinician's guide to X-linked hypophosphatemia. J Bone Miner Res Off J Am Soc Bone Miner Res. 2011;26:1381-8.

3. Linglart A, Biosse-Duplan M, Briot K, Chaussain C, Esterle L, Guillaume-Czitrom S, et al. Therapeutic management of hypophosphatemic rickets from infancy to adulthood. Endocr Connect. 2014;3:R13-30.

4. Che H, Roux C, Etcheto A, Rothenbuhler A, Kamenicky P, Linglart A, et al. Impaired quality of life in adults with X-linked hypophosphatemia and skeletal symptoms. Eur J Endocrinol. 2016;174:325-33.

5. Mäkitie O, Doria A, Kooh SW, Cole WG, Daneman A, Sochett E. Early treatment improves growth and biochemical and radiographic outcome in X-linked hypophosphatemic rickets. J Clin Endocrinol Metab. 2003;88:3591-7.

6. Chaussain-Miller C, Sinding C, Wolikow M, Lasfargues J-J, Godeau G, Garabédian M. Dental abnormalities in patients with familial hypophosphatemic vitamin D-resistant rickets: : prevention by early treatment with 1-hydroxyvitamin D. J Pediatr. $2003 ; 142: 324-31$.

7. Biosse Duplan M, Coyac BR, Bardet C, Zadikian C, Rothenbuhler A, Kamenicky P, et al. Phosphate and vitamin d prevent periodontitis in X-linked hypophosphatemia. J Dent Res. 2017;96:388-95.

8. Cheung M, Roschger P, Klaushofer K, Veilleux L-N, Roughley P, Glorieux FH, et al. Cortical and trabecular bone density in X-linked hypophosphatemic rickets. J Clin 
Endocrinol Metab. 2013;98:E954-961.

9. Gaucher C, Walrant-Debray O, Nguyen TM, Esterle L, Garabedian M, Jehan F. PHEX analysis in 118 pedigrees reveals new genetic clues in hypophosphatemic rickets. Hum Genet. 2009;125:401-11.

10. Brodehl J, Krause A, Hoyer PF. Assessment of maximal tubular phosphate reabsorption: : comparison of direct measurement with the nomogram of Bijvoet. Pediatr Nephrol Berl Ger. 1988;2:183-9.

11. Santos F, Fuente R, Mejia N, Mantecon L, Gil-Peña H, Ordoñez FA. Hypophosphatemia and growth. Pediatr Nephrol Berl Ger. 2013;28:595-603.

12. Greene WB. Genu varum and genu valgum in children: : differential diagnosis and guidelines for evaluation. Compr Ther. 1996;22:22-9.

13. Beck-Nielsen SS, Brusgaard K, Rasmussen LM, Brixen K, Brock-Jacobsen B, Poulsen MR, et al. Phenotype presentation of hypophosphatemic rickets in adults. Calcif Tissue Int. 2010;87:108-19.

14. Chesher D, Oddy M, Darbar U, Sayal P, Casey A, Ryan A, et al. Outcome of adult patients with X-linked hypophosphatemia caused by PHEX gene mutations. J Inherit Metab Dis. 19 2018; 41:865-76.

15. Alejo L, Corredoira E, Sánchez-Muñoz F, Huerga C, Aza Z, Plaza-Núñez R, et al. Radiation dose optimisation for conventional imaging in infants and newborns using automatic dose management software: an application of the new 2013/59 EURATOM directive. Br J Radiol. 2018;91:20180022.

16. Hardy DC, Murphy WA, Siegel BA, Reid IR, Whyte MP. X-linked hypophosphatemia in adults: prevalence of skeletal radiographic and scintigraphic features. Radiology. 1989;171:403-14.

17. Melhem E, Assi A, El Rachkidi R, Ghanem I. EOS(®) biplanar X-ray 
imaging: concept, developments, benefits, and limitations. J Child Orthop. 2016;10:1-14. 18. Gjørup H, Kjaer I, Beck-Nielsen SS, Poulsen MR, Haubek D. A radiological study on intra- and extra-cranial calcifications in adults with X-linked hypophosphatemia and associations with other mineralizing enthesopathies and childhood medical treatment. Orthod Craniofac Res. 2016;19:114-25.

19. Connor J, Olear EA, Insogna KL, Katz L, Baker S, Kaur R, et al. Conventional therapy in adults with X-linked hypophosphatemia: Effects on enthesopathy and dental disease. J Clin Endocrinol Metab. 2015;100:3625-32.

20. Schmitt CP, Mehls O. The enigma of hyperparathyroidism in hypophosphatemic rickets. Pediatr Nephrol Berl Ger. 2004;19:473-7.

21. Makitie O, Kooh SW, Sochett E. Prolonged high-dose phosphate treatment: : a risk factor for tertiary hyperparathyroidism in X-linked hypophosphatemic rickets. Clin Endocrinol Oxf. 2003;58:163-8.

22. Jonsson KB, Zahradnik R, Larsson T, White KE, Sugimoto T, Imanishi Y, et al. Fibroblast growth factor 23 in oncogenic osteomalacia and X-linked hypophosphatemia. $\mathrm{N}$ Engl J Med. 2003;348:1656-63.

23. Carpenter TO, Insogna KL, Zhang JH, Ellis B, Nieman S, Simpson C, et al. Circulating levels of soluble klotho and FGF23 in X-linked hypophosphatemia: circadian variance, effects of treatment, and relationship to parathyroid status. J Clin Endocrinol Metab. 2010;95:E352-357.

24. Vega RA, Opalak C, Harshbarger RJ, Fearon JA, Ritter AM, Collins JJ, et al. Hypophosphatemic rickets and craniosynostosis: a multicenter case series. J Neurosurg Pediatr. 2016;17:694-700.

25. Pantel G, Probst R, Podvinec M, Gurtler N. Hearing loss and fluctuating hearing levels in X-linked hypophosphataemic osteomalacia. J Laryngol Otol. 2009;123:136-40. 
26. Verge CF, Lam A, Simpson JM, Cowell CT, Howard NJ, Silink M. Effects of therapy in X-linked hypophosphatemic rickets. N Engl J Med. 1991;325:1843-8.

27. Veilleux LN, Cheung MS, Glorieux FH, Rauch F. The muscle-bone relationship in X-linked hypophosphatemic rickets. J Clin Endocrinol Metab. 2013;98:E990-5.

28. Saraff V, Schneider J, Colleselli V, Ruepp M, Rauchenzauner M, Neururer S, et al. Sex-, age-, and height-specific reference curves for the 6-min walk test in healthy children and adolescents. Eur J Pediatr. 2015;174:837-40.

29.

hypophosphatemies_hereditaires_a_fgf23_eleve_dont_hypophosphatemies_liees_a_l x_-_pnds.pdf [Internet]. [cité 19 août 2018]. Disponible sur: https://www.hassante.fr/portail/upload/docs/application/pdf/2018-

05/hypophosphatemies_hereditaires_a_fgf23_eleve_dont_hypophosphatemies_liees_a_lx__pnds.pdf

30. Gizard A, Rothenbuhler A, Pejin Z, Finidori G, Glorion C, de Billy B, et al. Outcomes of orthopedic surgery in a cohort of 49 patients with X-linked hypophosphatemic rickets (XLHR). Endocr Connect. 1 2017;6:566-73.

31. 761068s000lbl.pdf [Internet]. [accessed on June 27, 2018]. Available at https://www.accessdata.fda.gov/drugsatfda_docs/label/2018/761068s000lbl.pdf 32. WC500245537.pdf [Internet]. [accessed on June 27, 2018]. Available at http://www.ema.europa.eu/docs/en_GB/document_library/EPAR__Product_Information/human/004275/WC500245537.pdf

33. Carpenter TO, Whyte MP, Imel EA, Boot AM, Högler W, Linglart A, et al. Burosumab therapy in children with X-linked hypophosphatemia. N Engl J Med. 2018;378:1987-98.

34. Presentations \& Publications | Rare Disease Drug Development | Ultragenyx 
[Internet]. [accessed on February cité 10, 2018]. Available at http://www.ultragenyx.com/pipeline/publications/

35. Živičnjak M, Schnabel D, Staude H, Even G, Marx M, Beetz R, et al. Three-year growth hormone treatment in short children with X-linked hypophosphatemic rickets:

Effects on linear growth and body disproportion. J Clin Endocrinol Metab. 2011;96:E2097-105.

36. Rothenbuhler A, Esterle L, Gueorguieva I, Salles J-P, Mignot B, Colle M, et al. Twoyear recombinant human growth hormone $(\mathrm{rhGH})$ treatment is more effective in pre-pubertal compared to pubertal short children with X-linked hypophosphatemic rickets (XLHR). Growth Horm IGF Res. 2017;36:11-5.

37. Danino B, Rödl R, Herzenberg JE, Shabtai L, Grill F, Narayanan U, et al. Guided growth: preliminary results of a multinational study of 967 physes in 537 patients. J Child Orthop. 2018;12:91-6.

38. Sullivan W, Carpenter T, Glorieux F, Travers R, Insogna K. A prospective trial of phosphate and 1,25-dihydroxyvitamin D3 therapy in symptomatic adults with X-linked hypophosphatemic rickets. J Clin Endocrinol Metab.1992;75:879-85.

39. Nielsen LH, Rahbek ET, Beck-Nielsen SS, Christesen HT. Treatment of hypophosphataemic rickets in children remains a challenge. Dan Med J. 2014;61:A4874. 40. McAlindon TE, Bannuru RR, Sullivan MC, Arden NK, Berenbaum F, BiermaZeinstra SM, et al. OARSI guidelines for the non-surgical management of knee osteoarthritis. Osteoarthritis Cartilage. 2014;22:363-88.

41. Insogna KL, Briot K, Imel EA, Kamenický P, Ruppe MD, Portale AA, et al. A randomized, double-blind, placebo-controlled, phase 3 trial evaluating the efficacy of burosumab, an anti-FGF23 antibody, in adults with X-linked hypophosphatemia: Week 24 primary analysis. J Bone Miner Res 2018; 33:1383-1393 
42. Presentations \& Publications | Rare Disease Drug Development | Ultragenyx [Internet]. [accessed on February 10, 2018]. Available at http://www.ultragenyx.com/pipeline/publications/

43. Turan S, Topcu B, Gökçe İ, Güran T, Atay Z, Omar A, et al. Serum alkaline phosphatase levels in healthy children and evaluation of alkaline phosphatase z-scores in different types of rickets. J Clin Res Pediatr Endocrinol. 2011;3:7-11. 


\section{FIGURE LEGENDS}

Figure 1: Typical lower-limb deformities in three children with X-linked hypophosphatemia (a, c, e); the radiographs show signs of rickets with cortical hypertrophy and absence of bone resorption $(\mathbf{b}, \mathbf{d}, \mathbf{f}, \mathbf{g})$.

Figure 2: Clinical symptoms of X-linked hypophosphatemia in adults: multiple dental treatments (arrow 3), loss of teeth (arrow 1), periodontitis and taurodontism (arrow 1) (a); residual lower-limb deformities and overweight (b, c); enthesopathies (arrows 2 and 3), early osteoarthritis (arrow 1) and Looser zone (arrow 4) (d).

Figure 3: Improvements in the lower-limb deformities during conventional treatment by an active vitamin $\mathrm{D}$ analog and phosphate supplementation. The results are satisfactory in $\mathbf{a}, \mathbf{b}$, $\mathbf{c}, \mathbf{d}, \mathbf{e}$, and $\mathbf{f}$; inadequate in $\mathbf{g}, \mathbf{h}, \mathbf{i}$, and $\mathbf{j}$; and poor in $\mathbf{k}, \mathbf{l}, \mathbf{m}$, and $\mathbf{n}$. 
Table 1: Diagnosis of X-linked hypophosphatemia

\begin{tabular}{|c|c|c|c|c|}
\hline & $\begin{array}{l}\text { Neonate } \\
\text { Familial } \\
\text { disease }\end{array}$ & $\begin{array}{l}\text { Child } \\
\text { Familial } \\
\text { disease } \\
\end{array}$ & $\begin{array}{l}\text { Infant or Child } \\
\text { De novo disease }\end{array}$ & $\begin{array}{l}\text { Adult } \\
\text { Symptomatic }\end{array}$ \\
\hline $\begin{array}{l}\text { Physical } \\
\text { findings }\end{array}$ & & & $\begin{array}{l}\text { History of lower-limb } \\
\text { deformities in the patient } \\
\text { or family, dental disease, } \\
\text { bone pain, and/or short } \\
\text { stature }\end{array}$ & \\
\hline Radiographs & & $\begin{array}{l}\text { Left hand } \\
\text { and wrist } \\
\text { (bone age) } \\
\text { Lower } \\
\text { limbs } \\
\text { (standing, } \\
\text { AP view) }\end{array}$ & $\begin{array}{l}\text { Left hand and wrist (bone } \\
\text { age) } \\
\text { Lower limbs (standing, } \\
\text { AP view) } \\
\pm \text { Hips and lumbar spine }{ }^{\text {a }}\end{array}$ & Centered on painful sites \\
\hline $\begin{array}{l}\text { Blood } \\
\text { biochemistry }\end{array}$ & $\begin{array}{l}\text { Phosphate } \\
\text { ALP } \\
\text { Creatinine }\end{array}$ & $\begin{array}{l}\text { Phosphate, } \\
\text { calcium } \\
\text { ALP } \\
\text { Creatinine } \\
\text { PTH }\end{array}$ & $\begin{array}{l}\text { Phosphate, calcium } \\
\text { ALP } \\
\text { Creatinine } \\
\text { PTH } \\
25(\mathrm{OH}) \mathrm{D} ; 1,25(\mathrm{OH})_{2} \mathrm{D} \\
\text { Electrolytes }\end{array}$ & $\begin{array}{l}\text { Phosphate, calcium } \\
\text { ALP } \\
\text { Creatinine } \\
\text { PTH } \\
25(\mathrm{OH}) \mathrm{D} ; 1,25(\mathrm{OH})_{2} \mathrm{D} \\
\text { Electrolytes }^{\mathrm{b}}\end{array}$ \\
\hline $\begin{array}{l}\text { Urinary } \\
\text { biochemistry }\end{array}$ & $\begin{array}{l}\text { Phosphate } \\
\text { Creatinine }\end{array}$ & $\begin{array}{l}\text { Phosphate } \\
\text { Creatinine } \\
\text { Calcium }\end{array}$ & $\begin{array}{l}\text { Phosphate } \\
\text { Creatinine } \\
\text { Calcium } \\
\text { Electrolytes }\end{array}$ & $\begin{array}{l}\text { Phosphate } \\
\text { Creatinine } \\
\text { Calcium } \\
\text { Electrolytes }{ }^{b}\end{array}$ \\
\hline Confirmation & $\begin{array}{l}\text { Genetic } \\
\text { testing: } \\
\text { PHEX }\end{array}$ & $\begin{array}{l}\text { Genetic } \\
\text { testing: } \\
\text { PHEX }\end{array}$ & $\begin{array}{l}\text { Intact FGF23 } \\
\text { Genetic testing: PHEX }\end{array}$ & $\begin{array}{l}\text { Intact FGF23 } \\
\text { Genetic testing: } P H E X\end{array}$ \\
\hline
\end{tabular}

AP, anteroposterior; ALP, alkaline phosphatase; PTH, parathyroid hormone

${ }^{a}$ to rule out causes of bone dysplasia

${ }^{b}$ to rule out other renal tubule disorders 
Table 2: Treatment of X-linked hypophosphatemia: goals and monitoring

\begin{tabular}{|c|c|c|c|c|c|c|c|}
\hline & \multicolumn{4}{|c|}{$\begin{array}{l}\text { Active vitamin D analog and phosphate } \\
\text { supplementation }\end{array}$} & \multicolumn{3}{|c|}{ Burosumab (42) } \\
\hline & $\begin{array}{l}\text { Neonate } \\
\text { Familial } \\
\text { disease }\end{array}$ & \multicolumn{2}{|c|}{ De novo XLH } & Adults & \multicolumn{3}{|c|}{ Children >1 year } \\
\hline $\begin{array}{l}\text { Starting } \\
\text { dosage }\end{array}$ & $\begin{array}{l}\text { Alfacalcidol: } \\
1 \mu \mathrm{g} / \text { day } \\
\text { Phosphate: } \\
50- \\
60 \mathrm{mg} / \mathrm{kg} / \mathrm{j} \\
\text { (in } 4 \text { daily } \\
\text { doses) } \\
\end{array}$ & \multicolumn{2}{|c|}{$\begin{array}{l}\text { Alfacalcidol: } \\
1-1.5 \mu \mathrm{g} / \mathrm{day} \\
\text { Phosphate: } \\
40-60 \mathrm{mg} / \mathrm{kg} / \text { day (in } \\
4 \text { daily doses) }\end{array}$} & $\begin{array}{l}\text { Alfacalcidol: } \\
1-1.5 \mu \mathrm{g} / \mathrm{day} \\
\text { Calcitriol: } \\
0.5-0.75 \mu \mathrm{g} / \mathrm{day} \\
\text { Phosphate: } \\
\text { 0-2500 mg/jour } \\
\text { (in } 2 \text { daily doses) }\end{array}$ & \multicolumn{3}{|c|}{$0.4 \mathrm{mg} / \mathrm{kg}$ in Europe } \\
\hline \multirow[t]{2}{*}{$\begin{array}{l}\text { Maintenance } \\
\text { dosage }\end{array}$} & \multicolumn{3}{|c|}{$\begin{array}{l}\text { Alfacalcidol: } 1-2 \mu \mathrm{g} / \mathrm{day} \\
\text { Phosphate: } 30-60 \mathrm{mg} / \mathrm{kg} / \text { day (in } 3 \\
\text { daily doses) }\end{array}$} & $\begin{array}{l}\text { Alfacalcidol: } \\
0.5-1.5 \mu \mathrm{g} / \text { day } \\
\text { Calcitriol: } \\
0.25-0.5 \mu \mathrm{g} / \text { day } \\
\text { Phosphate: } \\
0-2500 \mathrm{mg} / \text { day } \\
\text { (in } 2 \text { daily doses) }\end{array}$ & \multicolumn{3}{|c|}{$\sim 1 \mathrm{mg} / \mathrm{kg}$} \\
\hline & Marker & $\begin{array}{l}\text { Time- } \\
\text { frame }\end{array}$ & $\begin{array}{l}\text { Inter- } \\
\text { vention }\end{array}$ & & $\begin{array}{l}\text { Mar- } \\
\text { ker }\end{array}$ & $\begin{array}{l}\text { Ti } \\
\text { me- } \\
\text { fra } \\
\text { me }\end{array}$ & Intervention \\
\hline \multirow{4}{*}{ 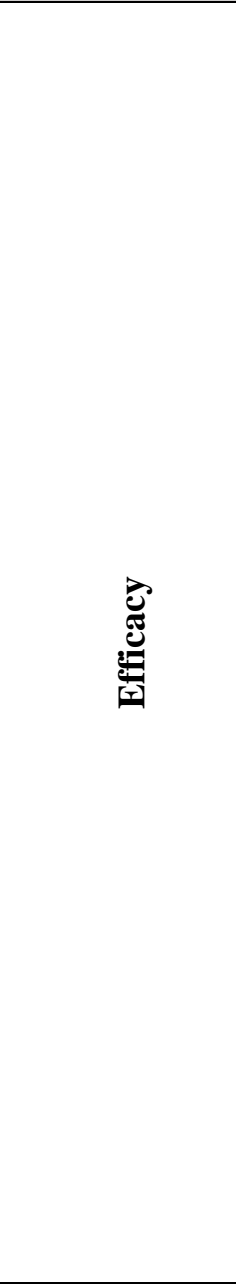 } & & & & & $\begin{array}{l}\text { Phos } \\
\text { phate }\end{array}$ & $\begin{array}{l}2-4 \\
\text { mo } \\
\text { nth } \\
\text { s }\end{array}$ & $\begin{array}{l}\text { Burosumab } \\
\text { dosage } \\
\text { titration in } \\
0.4 \mathrm{mg} / \mathrm{kg} \\
\text { increments } \\
\text { every } 4 \text { weeks }\end{array}$ \\
\hline & & & & & $\begin{array}{l}\text { Urina } \\
\text { ry } \\
\text { phos } \\
\text { phate } \\
\text { excre } \\
\text { tion } \\
\text { (TRP } \\
\text { TmP/ } \\
\text { GFR) }\end{array}$ & $\begin{array}{l}2-4 \\
\text { mo } \\
\text { nth } \\
\text { s }\end{array}$ & \\
\hline & & & & & $\begin{array}{l}1,25 \\
(\mathrm{OH}) \\
{ }_{2} \mathrm{D}\end{array}$ & $\begin{array}{l}2-4 \\
\text { mo } \\
\text { nth } \\
\mathrm{s}\end{array}$ & \\
\hline & ALP & $\begin{array}{l}6-12 \\
\text { months }\end{array}$ & $\begin{array}{l}\text { Adjust } \\
\text { dosage } \\
\text { of } \\
\text { vitamin } \\
\text { D } \\
\text { analogs } \\
\text { and/or } \\
\text { phos- } \\
\text { phate }\end{array}$ & & ALP & $\begin{array}{l}6- \\
12 \\
\text { mo } \\
\text { nth } \\
\text { s }\end{array}$ & \\
\hline
\end{tabular}




\begin{tabular}{|c|c|c|c|c|c|c|c|}
\hline & $\begin{array}{l}\text { Improvement } \\
\text { in lower-limb } \\
\text { deformities }\end{array}$ & $3-4$ years & 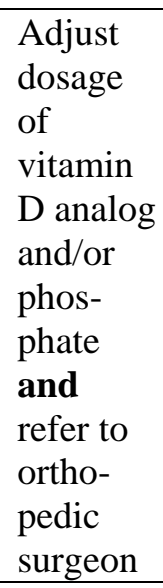 & & $\begin{array}{l}\text { Impr } \\
\text { ovem } \\
\text { ent in } \\
\text { lower } \\
\text {-limb } \\
\text { defor } \\
\text { mitie } \\
\text { s }\end{array}$ & & $\begin{array}{l}\text { Burosumab } \\
\text { dosage } \\
\text { adjustment } \\
\text { and } \\
\text { refer to } \\
\text { orthopedic } \\
\text { surgeon }\end{array}$ \\
\hline & $\begin{array}{l}\text { Pain relief, } \\
\text { fracture } \\
\text { healing }\end{array}$ & $\begin{array}{l}\text { Several } \\
\text { months }\end{array}$ & & $\begin{array}{l}\text { Adjust dosage of } \\
\text { vitamin D analog } \\
\text { and/or phosphate } \\
\text { and } \\
\text { refer to orthopedic } \\
\text { surgeon }\end{array}$ & $\begin{array}{l}6 \mathrm{M} \\
\mathrm{WT}\end{array}$ & $\begin{array}{l}12 \\
\text { mo } \\
\text { nth } \\
\mathrm{s}\end{array}$ & \\
\hline & & & & & $\begin{array}{l}\text { RGI- } \\
\text { C } \\
\text { (lowe } \\
\text { r- } \\
\text { limb } \\
\text { radio } \\
\text { graph } \\
\text { s) } \\
\end{array}$ & $\begin{array}{l}10- \\
12 \\
\text { mo } \\
\text { nth } \\
\text { s }\end{array}$ & \\
\hline & $\begin{array}{l}\text { Height } \\
\text { Improve } \\
\text { linear growth } \\
\text { rate }\end{array}$ & 1 year & 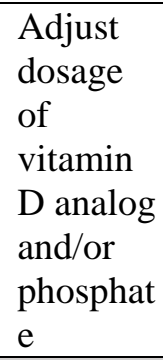 & & $\begin{array}{l}\text { Impr } \\
\text { ove } \\
\text { linear } \\
\text { grow } \\
\text { th } \\
\text { rate }\end{array}$ & $?$ & $?$ \\
\hline & Marker & $\begin{array}{l}\text { Follow- } \\
\text { up } \\
\text { interval }\end{array}$ & & & $\begin{array}{l}\text { Mar } \\
\text { ker }\end{array}$ & $\begin{array}{l}\text { Fol } \\
\text { low } \\
\text {-up } \\
\text { inte } \\
\text { rva } \\
\text { l }\end{array}$ & \\
\hline \multirow{5}{*}{ 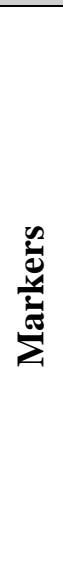 } & $\begin{array}{l}\text { Serum } \\
\text { calcium }\end{array}$ & \multicolumn{3}{|c|}{ 3-6-12 months } & $\begin{array}{l}\text { Seru } \\
\mathrm{m} \\
\text { calci } \\
\text { um } \\
\end{array}$ & \multicolumn{2}{|c|}{ 3-6 months } \\
\hline & $\begin{array}{l}\text { Urinary } \\
\text { calcium }\end{array}$ & \multicolumn{3}{|c|}{ 3-6-12 months } & $\begin{array}{l}\text { Urina } \\
\text { ry } \\
\text { calci } \\
\text { um }\end{array}$ & \multicolumn{2}{|c|}{ 3-6 months } \\
\hline & PTH & \multicolumn{3}{|c|}{ 3-6-12 months } & PTH & \multicolumn{2}{|c|}{ 3-6 months } \\
\hline & $25(\mathrm{OH}) \mathrm{D}$ & \multicolumn{3}{|c|}{ 6-12 months } & $\begin{array}{l}25(\mathrm{O} \\
\mathrm{H}) \mathrm{D}\end{array}$ & \multicolumn{2}{|c|}{ 6-12 months } \\
\hline & $\begin{array}{l}\text { Renal } \\
\text { ultrasound }\end{array}$ & \multicolumn{3}{|l|}{$1-2$ years } & $\begin{array}{l}\text { Rena } \\
1\end{array}$ & \multicolumn{2}{|c|}{$1-2$ years } \\
\hline
\end{tabular}




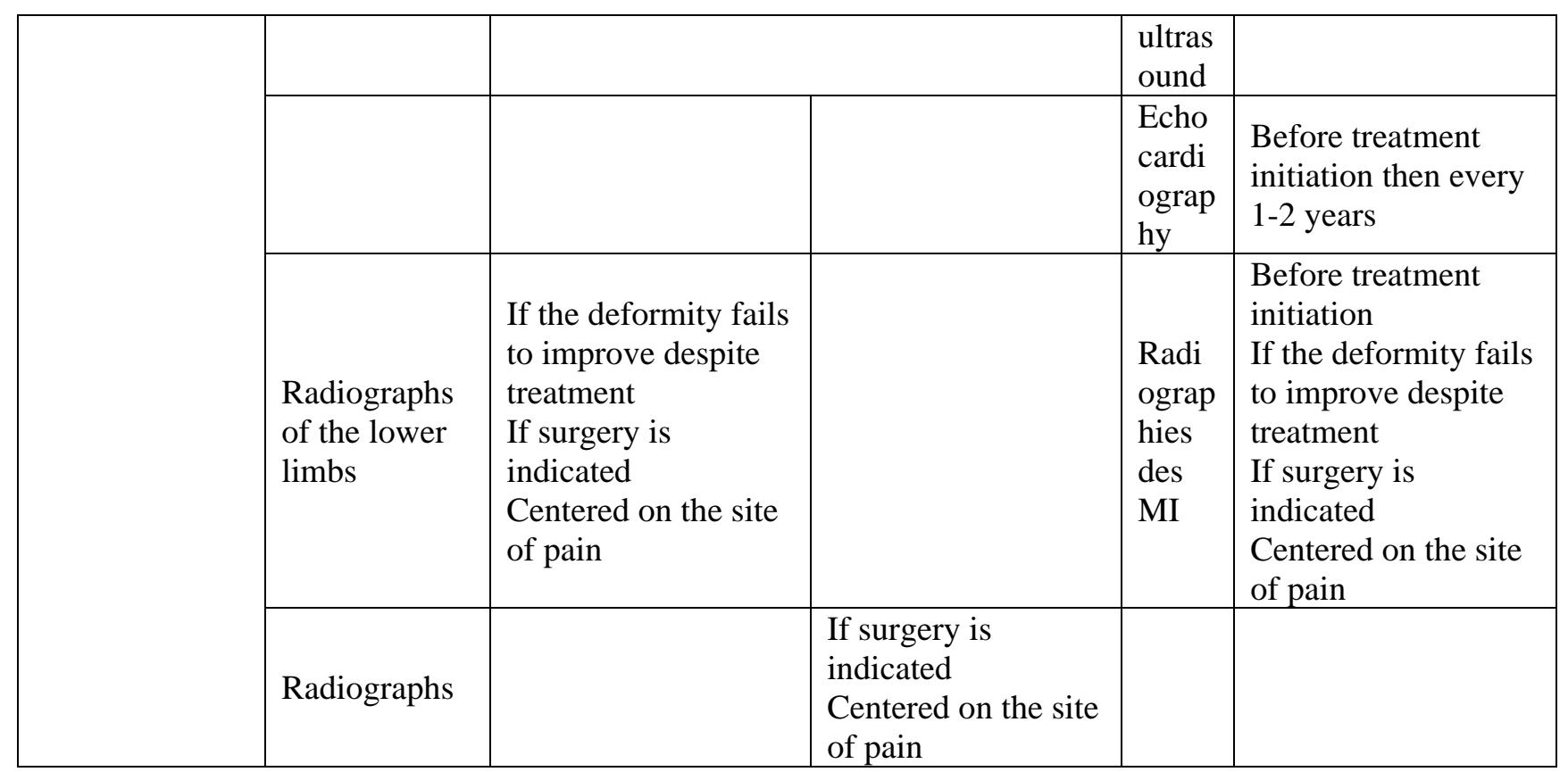

TmPi/GFR, maximal tubular phosphate reabsorption rate, relative to the glomerular filtration

rate; ALP, alkaline phosphatase (43); 6MWT, 6-minute walking test (28); RGI-C,

Radiographic Global Impression Of Change (rickets score) 


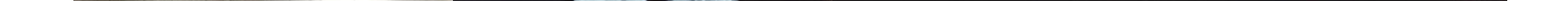



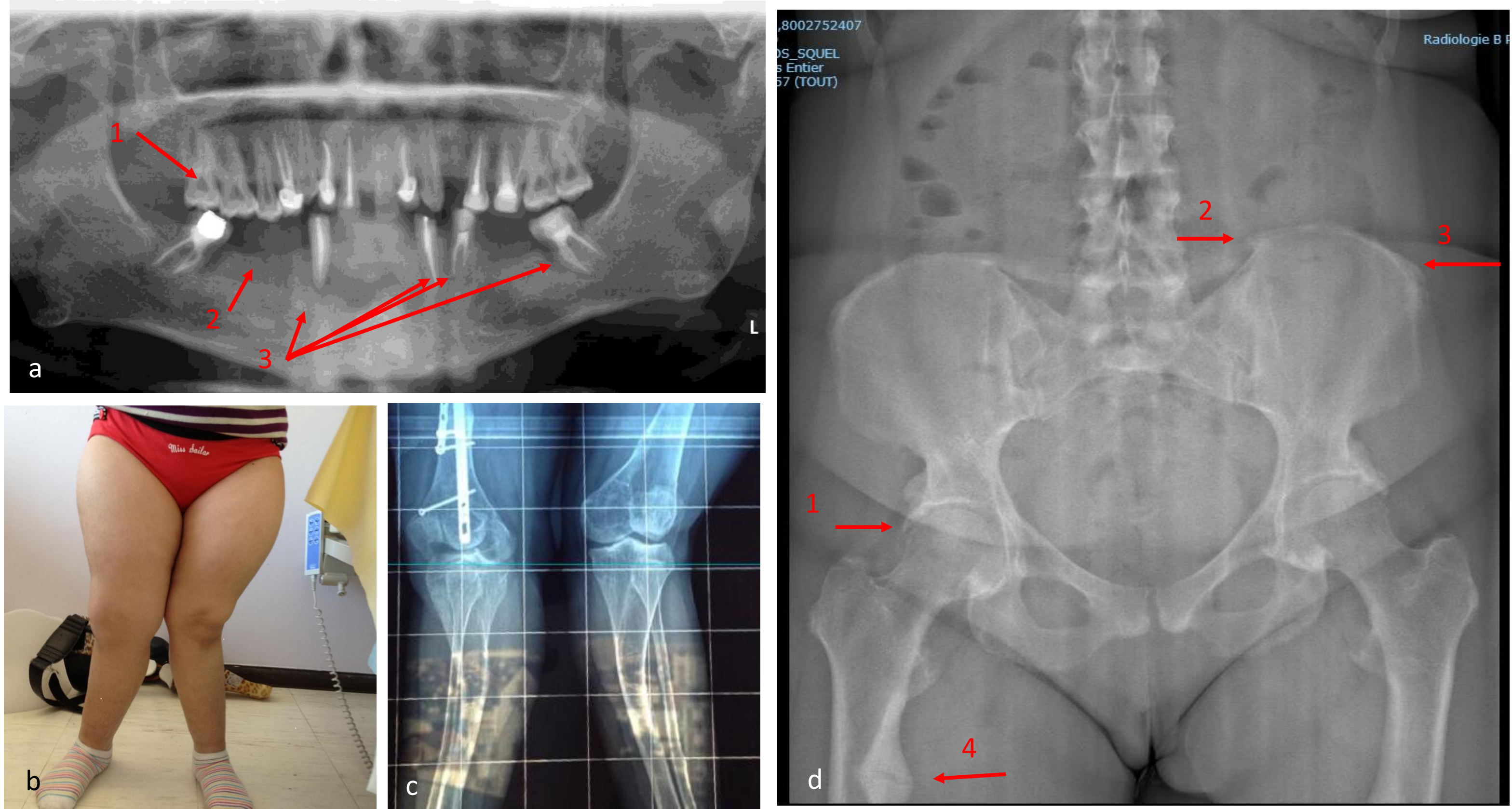

Figure 2 
